\title{
$\mathrm{Al}-\mathrm{Si}$ 도금된 핫스탬핑 보론강 볼트 프로젝션 용접 시 도금층 용융 거동이 용접성에 미치는 영향
}

\author{
김재훈 ${ }^{*}$ 전현욱 ${ }^{* *} \cdot$ 천주용 ${ }^{*}$ - 김양도** \\ *한국생산기술연구원 울산지역본부 첨단정형공정그룹 \\ **부산대학교 재료공학과
}

\section{Effect of the Melting Behavior of the Coating Layer on Weldability in the Bolt Projection Resistance Welding of Al-Si Coated Hot-Stamped Boron Steel}

\author{
Jae-Hun Kim*, Hyun-Uk Jun**, Joo-Yong Cheon*, Yang-Do Kim** and Changwook Ji*, ${ }^{*}$ \\ *Ulsan Regional Division, Korea Institute of Industrial Technology, Ulsan, 44776, Korea \\ **Dept. of Material Science and Engineering, Pusan National University, Busan, 46241, Korea
}

†Corresponding author : cwji@kitech.re.kr

(Received January 10, 2020 ; Revised January 28, 2020 ; Accepted February 3, 2020)

\begin{abstract}
In this study, the effect of $\mathrm{Al}-\mathrm{Si}$ coating melting behavior and weldability during the resistance spot welding of hot stamped boron steels was investigated. In the case of the Al-Si coated hot-stamped boron steel, high heat was generated on the surface and the oxide layer by the intermetallic coating, and the molten coating layer pushed toward the outer edge of the weld like a film of liquid. The liquid coating layer accumulated at the periphery, preventing current flow and extension of the contact area, and this influenced the height of the nugget growth. As a result of the limited nugget growth, weld strength decreased. However, in the case of bare hot stamped boron steel, relatively low heat was generated due to the large contact area, and the nugget grew in the longitudinal direction. Compared to the nugget diameter of Al-Si coated hot-stamped boron steel, this can result in superior weldability.
\end{abstract}

Key Words : Bolt projection welding, Al-Si coated hot stamping steel, Melting behavior, Weldability, Heat generation

\section{1. 서 론}

최근 지구온난화 및 미세먼지 등의 환경문제로 인해 세계 각국에서 $\mathrm{CO}_{2}$ 저감 및 연비 규제를 위한 다양한 노력들이 시도되고 있으며 이를 대응하기 위해 국내외 자동차사는 차체 경량화, 연비 증대, 친환경 동력원 적 용 등과 같은 기술 개발을 진행 중에 있다. 전기 및 친 환경 연료 자동차의 경우 연비 향상 및 주행거리 연장 을 위한 차체 경량화 기술 개발은 필수적이며, 그 중 두께 감소 및 강성 확보를 위한 초고장력 강판을 이용
하여 경량화와 차체 안전성을 동시에 만족하는 기술이 현실적인 대안으로 각광받고 있다. 초고장력 강판은 스 프링백 현상 및 냉간 성형이 어려워 이를 극복하기 위 해 핫스탬핑 공법(가열된 강판을 금형으로 급속 냉각시 켜 고강도를 확보할 수 있는 공법)을 이용하여 자동차 차체 부품의 $\mathrm{A}$ 필러, $\mathrm{B}$ 필러, 사이드 아우터, 범퍼 등 충격 특성을 요구하는 주요 부품에 적용되어지고 있다 1). 핫스탬핑 보론강의 경우 $900 \sim 950{ }^{\circ} \mathrm{C}$ 고온 환경에 서 제조되기 때문에 강판 표면의 산화 스케일 및 표면 탈탄 등의 문제가 있다. 이를 방지하기 위해 표면에 $\mathrm{Al}-\mathrm{Si}$ 도금 처리를 하고 있고, 열처리 과정에서 모재의 
$\mathrm{Fe}$ 가 $\mathrm{Al}-\mathrm{Si}$ 도금층에 확산되어 $\mathrm{Fe}-\mathrm{Al}-\mathrm{Si}$ 중간화합물 층이 생성되는 것으로 알려져 있달.

$\mathrm{Al}-\mathrm{Si}$ 도금된 핫스탬핑 보론강의 표면은 외각의 $\mathrm{Fe}^{-}$ $\mathrm{Al}-\mathrm{Si}$ 복잡한 합금화층 및 산화층으로 구성되어 있고, 모재의 높은 강성으로 인하여 저항용접 시 비산현상, 표면균열, 용접부 계면파단, 인장강도/전단강도 저하 등의 공정 및 품질 문제가 지속적으로 발생하고 있으며 연강(Mild steel)에 비해 좁은 가용전류구간으로 용접 성이 좋지 않다고 보고되어 있다 ${ }^{3-5)} . \mathrm{Ji}^{6)}$ 등은 저항 점 용접에서의 핫스탬핑 강판의 합금층의 영향을 비교 - 고 찰하고, 문제시되고 있는 용접성에 대한 부분을 해결 하기 위해 펄스 파형의 용접전류를 기반으로 최적의 용 접조건을 도출하였으며, $\mathrm{Lim}^{7)}$ 등 은 핫스탬핑 강판의 너트 프로젝션 용접 시 너트의 재질에 따른 용접성 비 교 및 파단 모드의 영향을 고찰하였으며, $\mathrm{Chun}^{8)}$ 등 은 핫스탬핑 강판의 너트 돌기 형상을 최적화하여 용접 부 인장강도 등 기계적 물성과 실제 $\mathrm{Al}-\mathrm{Si}$ 합금화층의 거동에 대해 비교·분석하였다.

앞서 언급한 바와 같이 $\mathrm{Al}-\mathrm{Si}$ 핫스탬핑 보론강의 저 항 용접에 대한 일부 연구결과가 보고된 바 있지만, 볼 트 프로젝션 용접에 대한 도금층 유무에 따른 용접 현 상과 용접 시 도금층의 거동에 대한 구체적인 연구 사 례 및 동저항(Dynamic Resistance)과 연관 지어 용 접성에 대해 고찰된 연구는 제한적이다. 특히, 볼트 프 로젝션 용접은 저항 점 용접 및 너트 프로젝션 용접과 유사한 원리이나 돌기 형상 차이 등으로 인한 용융 형 태 및 메커니즘, 용접 특성이 다르고, 다수의 돌기를 이용해 용접하기 때문에 모든 돌기 용접부에서 강도를 확보해야 하며 하나의 돌기 용접부에서 불량이 발생하 면 전체 접합 강도가 급격하게 감소되는 경향이 있다.

따라서 본 연구에서는 볼트 프로젝션 저항 용접 시 $\mathrm{Al}-\mathrm{Si}$ 도금층의 유무에 따른 동저항의 차이를 분석하고 $\mathrm{Al}-\mathrm{Si}$ 도금층의 초기 용융 거동 및 너겟 성장 거동을 비교하여 $\mathrm{Al}-\mathrm{Si}$ 핫스탬핑 보론강 볼트 프로젝션 용접 시 $\mathrm{Al}-\mathrm{Si}$ 도금층의 용융 거동이 용접성에 미치는 영향 을 고찰해보았다.

\section{2. 실험 방법}

본 연구에서는 $1.0 \mathrm{~mm}$ 두께의 $\mathrm{Al}-\mathrm{Si}$ 도금된 핫스탬 핑 보론강을 사용하였으며, Table. 1에 $\mathrm{Al}-\mathrm{Si}$ 도금된 핫스탬핑 보론강의 합금 조성 및 도금층의 성분을 나타 내었다. 핫스탬핑 처리는 $900{ }^{\circ} \mathrm{C}$ 에서 약 5 분간 유지 후 냉각 다이에서 급냉 하였고 도금층을 제거한 핫스탬 핑 보론강(이하 Bare 핫스탬핑 보론강)은 Silicon Carbide
Table 1 Chemical composition and coating properties of used hot stamped steel

\begin{tabular}{|c|c|c|c|c|c|}
\hline \multicolumn{7}{|c|}{ Chemical composition of base metal(wt \%) } \\
\hline $\mathrm{C}$ & $\mathrm{Si}$ & $\mathrm{Mn}$ & $\mathrm{P}$ & $\mathrm{S}$ & $\mathrm{Ceq}$ \\
\hline 0.23 & 0.26 & 1.24 & 0.0015 & 0.002 & 0.45 \\
\hline \multicolumn{6}{|c|}{ Chemical composition of coating $(\mathrm{wt} \%)$} \\
\hline $\mathrm{Al}$ & $\mathrm{Si}$ & & \\
\hline 90 & 10 &
\end{tabular}

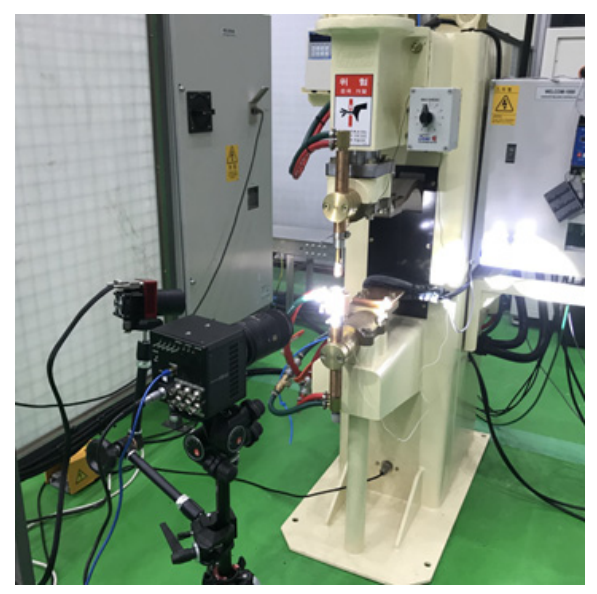

Fig. 1 Experimental machine of bolt projection welding

Paper를 사용하여 물리적으로 표면을 연마한 후, 화학 적 에칭 처리를 하였다. 볼트는 $\mathrm{KS} \mathrm{B} 1057$ 규격에 적 합한 머리부 지름 $14 \mathrm{~mm}$, 머리부 높이 $2 \mathrm{~mm}$, 용접 돌기부 지름 $2.5 \mathrm{~mm}$, 용접 돌기부 높이 $0.8 \mathrm{~mm}$, 나사길 이 $14 \mathrm{~mm}$ 의 M6 3점 돌기 용접 볼트를 사용하였다. 본 실험에 사용된 용접기의 사양은 전격 용량 $100 \mathrm{kVA}$, 제 어주파수 $1000 \mathrm{~Hz}$ 의 Inverter $\mathrm{DC}$ 정치식 공압 스폿 용접기이고 냉각수 $25{ }^{\circ} \mathrm{C}, 6.0 \mathrm{~L} / \mathrm{min}$ 의 냉각속도를 유지하였다. 고속 카메라 영상은 Fig. 1에서와 같이 구 성하여 촬영하였다.

가용전류구간을 비교하기 위한 용접조건은 작업 현장 조건을 반영한 가압력 $570 \mathrm{kgf}$, 용접 시간 16 Cycle 으로 고정하였으며, 압축 파단 실험을 하였을 때 3 점의 돌기가 모두 파단 되며 압축강도 $420 \mathrm{kgf}$ 이상을 만족 하는 전류 조건을 기준으로 중간날림(Expulsion) 발생 전류 조건을 상한 전류, 기준 전류 이하를 하한전류로 설정하였다. $\mathrm{Al}-\mathrm{Si}$ 도금층의 영향은 용접 전류와 전압 을 실시간 모니터링하여 얻은 동저항 곡선 결과를 바탕 으로 분석하였으며 용접 시뮬레이션 프로그램인 Sorpas@ (저항용접 해석 시뮬레이션)를 이용하여 용접 공정 중 온도 분포 및 용융 현상을 관찰하였고, $\mathrm{OM}$ 및 $\mathrm{EPMA}$ (Eectron Probe Micro Analysis)의 성분 매핑(Mapping) 
기법을 통해 초기 도금층의 용융 거동 현상을 고찰하였 다. 실제 용접 시 발생하는 도금층 및 용융부의 거동 관 찰을 위해 고속카메라(FastCAM Mini UX50 Model 160K C2 with F-mount Sigma MACRO 105MM lens)를 사용하였다.

\section{3. 결과 및 고찰}

\section{1 도금층 유무에 따른 가용전류 구간 비교}

핫스탬핑 보론강의 도금층의 영항을 비교해보기 위해 저항 용접 용접성의 중요한 인자 중의 하나인 가용전류 구간을 핫스탬핑 보론강의 도금층 유무에 따라 도출해 보았다. Fig. 2는 핫스탬핑 보론강의 도금층 유무에 따 른 (가압력과 용접 시간을 고정) 가용 전류 구간을 비 교한 그림이다. 용접 전류가 증가함에 따라 용접부 압 축강도가 증가하였으며 중간날림이 발생되는 $17 \mathrm{kA}$ 용 접 전류에서 압축강도가 급격하게 감소하였다. $\mathrm{Al}-\mathrm{Si}$ 도금된 핫스탬핑 보론강의 경우 전류 조건 $15 \mathrm{kA}$ 에서만 $436 \mathrm{kgf}$ 으로 나타났고, Bare 핫스탬핑 보론강의 경우 전류 조건 13 15 kA의 용접조건에서 최대 압축강도 $604 \mathrm{kgf}$ 로 $\mathrm{Al}-\mathrm{Si}$ 도금된 핫스탬핑 보론강 보다 Bare 핫스탬핑 보론강이 더 넓은 가용전류구간을 확보였다. 이는 핫스탬핑 보론강의 도금층의 존재 유무가 용접 특 성에 큰 영향을 미치고, 또한 도금층이 존재함으로 인 하여 발열현상이 가속화되어, 중간날림발생전류가 낮았 다고 판단되며, 용융 및 발열현상에 대해서는 다음 장 에서 자세히 고찰해보았다.

\section{2 동저항 곡선 및 해석시뮬레이션 비교}

용접 시간 동안 핫스탬핑 보론강의 도금층 유무에 따 른 용융 거동 및 발열 온도를 비교하기 위해 저항 용접 시뮬레이션(Sorpas@Simulator)을 이용해 Fig. 3과 같이 비교해보았다. Fig. 3(a)의 Bare 핫스탬핑 보론 강의 경우 용접 초기에 용접 돌기가 붕괴되기 시작하여

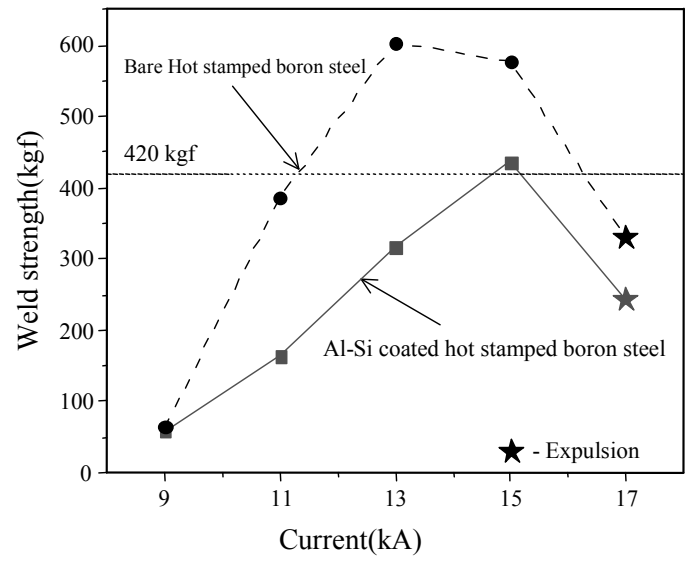

Fig. 2 Comparison of weldable current range of Al-Si coated and Bare hot stamped boron steel(electrode force : $570 \mathrm{kgf}$, weld time : 16 cycle)

통전면적이 확대됨에 따라 비교적 큰 너겟의 용융이 발 생하였으나, Fig. 3(b)의 Al-Si 도금된 핫스탬핑 보론 강은 용접 초기의 발열이 용접부 계면에서만 국부적으 로 발생, 용접 돌기가 붕괴되지 않아 충분한 통전면적 을 확보하지 못해 너겟크기가 상대적으로 작았다. 이때 용접부 최대 온도는 $\mathrm{Al}-\mathrm{Si}$ 도금된 핫스탬핑 보론강 $1580{ }^{\circ} \mathrm{C}$, Bare 핫스탬핑 보론강 $1523{ }^{\circ} \mathrm{C}$ 로 $\mathrm{Al}-\mathrm{Si}$ 도 금층 및 산화층의 존재로 용접부 계면에서 입열이 집중 적으로 발열이 발생하였다고 판단된다 ${ }^{8)}$.

저항용접의 용접 현상 즉, 접촉의 붕괴, 거친 표면 연 화, 온도 상승, 초기 용융, 너깃 성장, 날림 등의 현상 을 모니터링된 전류 및 전압의 산출 값으로 나타낸 것 이 동저항 신호이다. 이는 용융부 형성 과정에서부터 용접 종료까지의 다양한 정보를 직-간접적으로 갖고 있 으며, 이를 이용하여 용접품질의 예측에 대한 다양한 연구가 진행되었다 ${ }^{9-11)}$. 앞서 설명한 용접성에 차이가 발 생하는 원인에 대해 동저항 값을 통하여 비교·고찰해보 았다. Fig. 4는 Al-Si 도금된 핫스탬핑 보론강과 Bare 핫스탬핑 보론강을 동일 용접조건으로 용접 시 동저항 곡선을 비교한 결과이다. 먼저 표면조도가 붕괴되고 표 면 거칠기가 연화되어 동저항이 급격하게 하락하는 $a^{-}$

\begin{tabular}{|l|l|l|l|l|l|l|l|}
\hline & $5 \mathrm{~ms}$ & $15 \mathrm{~ms}$ & $25 \mathrm{~ms}$ & $35 \mathrm{~ms}$ & $85 \mathrm{~ms}$ & $125 \mathrm{~ms}$ & $185 \mathrm{~ms}$ \\
\hline (a) & & & & & & & \\
\hline
\end{tabular}

Fig. 3 Melting behavior by SORPAS simulation during projection welding, (a) bare Hot stamped boron steel (b) Al-Si coated hot stamped boron steel 


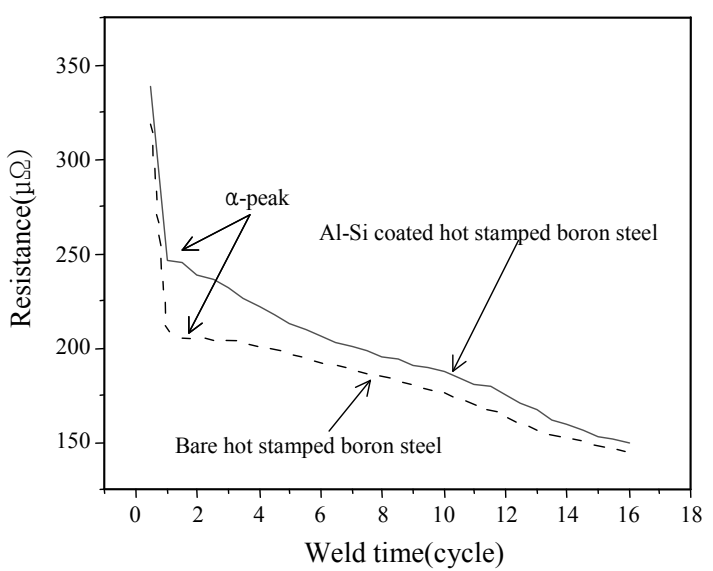

Fig. 4 Dynamic resistance curve with weld time for bolt projection welded Al-Si coated, and Bare hot stamped boron steel (electrode force $570 \mathrm{kgf}$ and weld time 16 cycle)

peak 의 경우 Bare 핫스탬핑 보론강 보다 $\mathrm{Al}-\mathrm{Si}$ 핫스 탬핑 보론강이 더 높았으며 이는 $\mathrm{Al}-\mathrm{Si}$ 합금화층 및 산 화층 존재로 인한 표면 저항값이 높았고, 합금화층 내 $\mathrm{Fe}$ 에 $\mathrm{Al}, \mathrm{Si}$ 가 일부 고용된 형태로 존재하는 합금화 층의 영향에 기인한 것이라 판단된다 ${ }^{12-13)}$.

용접 전류 조건에 따른 $\mathrm{Al}-\mathrm{Si}$ 도금층의 영향에 대한 동저항을 분석하기 위해 Fig. 5에 용접 전류 조건에 따 른 $\mathrm{Al}-\mathrm{Si}$ 도금된 핫스탬핑 보론강과 Bare 핫스탬핑 보 론강의 초기 동저항 및 동저항 곡선의 면적을 비교하여 나타냈다. 용접 전류가 증가됨에 따라 $\mathrm{Al}-\mathrm{Si}$ 도금된 핫 스탬핑 보론강의 동저항이 높게 나타났다. 이는 초기 높은 용접 전류가 통전됨에 따라 표면저항이 증가하기 때문이고, 용접 전류가 증가함에 따른 그래프의 적분값, 즉, 전체 저항값은 감소하게 되고 용접 전류의 증가함 에 따라 통전면적 확대로 인한 저항값의 감소했다고 판 단된다. 동저항에 대한 신호를 통하여 실제 용융 현상 에 대한 명확한 예측은 쉽지 않다. 따라서 $\mathrm{Al}-\mathrm{Si}$ 도금 층의 초기 용융 거동을 분석하여 표면발열 및 용접 강 도 저하의 원인을 규명하기 위해서는 볼트와 판재의 계 면 관찰을 통하여 초기 용융 현상을 분석하고 $\mathrm{Al}-\mathrm{Si}$ 도 금층이 용접성에 미치는 영향에 대해 고찰이 필요하다. 다음 장에서는 실제 용융 현상에 대해 고찰해 보았다.

\section{$3.3 \mathrm{Al}-\mathrm{Si}$ 도금층 초기용융 거동 분석}

저항 용접 공정 중 용접 초기에 용접부 계면 사이의 접촉면 붕괴, 접합계면의 연화등으로 접촉저항이 감소 함에 따른 전류 통전 면적이 확보되며 이러한 초기 용 융 현상은 용접성에 큰 영향을 미친다고 보고되었다 ${ }^{14)}$. 용접성에 대한 비교를 현상학적으로 분석하기 위해서는
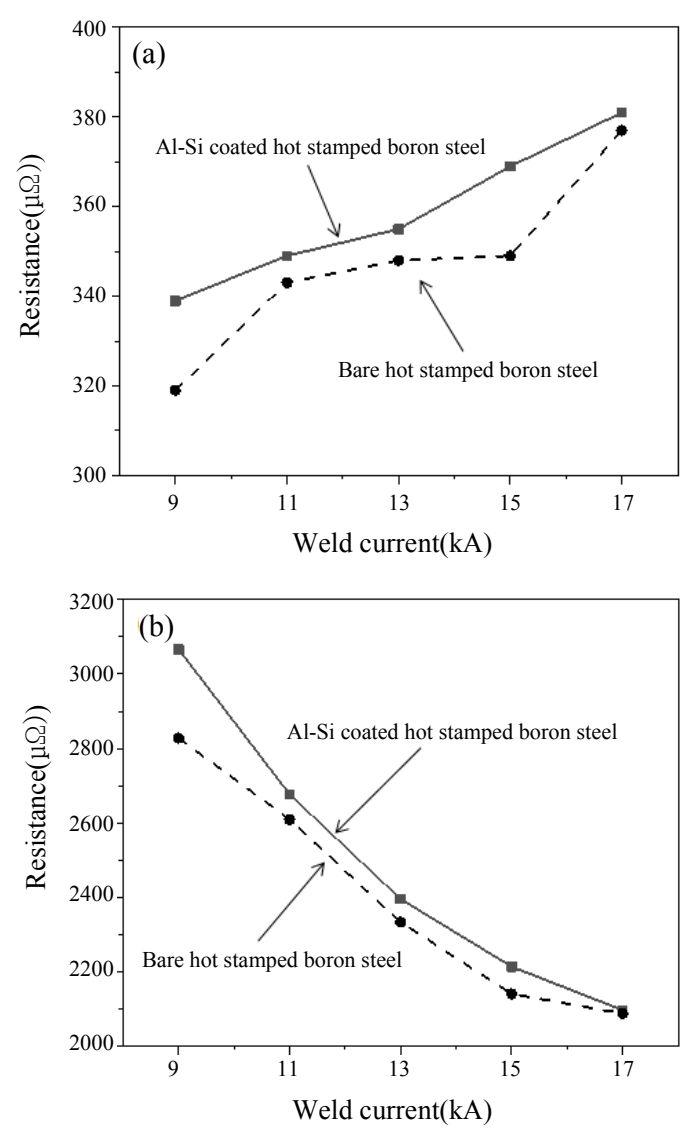

Fig. 5 Comparison of dynamic resistance for Bare and Al-Si coated hot stamped boron stee, (a) initial resistance (b) gross area resistance (electrode force $570 \mathrm{kgf}$ and weld current 16 cycle)

용접 초기 접합부의 융융 현상에 대해 자세한 분석이 필요하다. Fig. 6는 중간날림이 발생하지 않는 안정적 인 용접 전류 조건으로 짧은 시간 용접 $(2 \mathrm{cycle})$ 후 초 기 용융 현상을 관찰하기 위해 접합부 계면을 광학현미 경으로 관찰한 결과이다. Fig. $6(\mathrm{a})$ 의 경우 $\mathrm{Al}-\mathrm{Si}$ 도 금된 핫스탬핑 보론강의 초기 접촉 경은 약 $2.19 \mathrm{~mm}$, Bare 핫스탬핑 보론강 초기 접촉 경은 지름 약 $2.46 \mathrm{~mm}$ 로 $\mathrm{Al}-\mathrm{Si}$ 도금된 핫스탬핑 보론강의 접촉 면적이 상대 적으로 작게 관찰되었다. 또한 $\mathrm{Al}-\mathrm{Si}$ 도금된 핫스탬핑

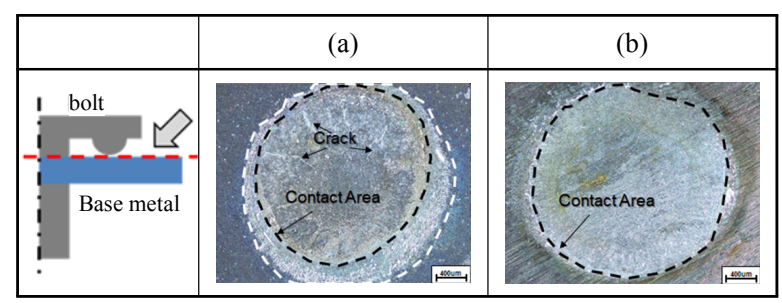

Fig. 6 Coating melting behavior at faying surface, (a) Al-Si coated hot stamped boron steel, (b) Bare hot stamped boron steel(electrode force $570 \mathrm{kgf}$ and weld current $11 \mathrm{kA}$ and weld time 2 cycle) 


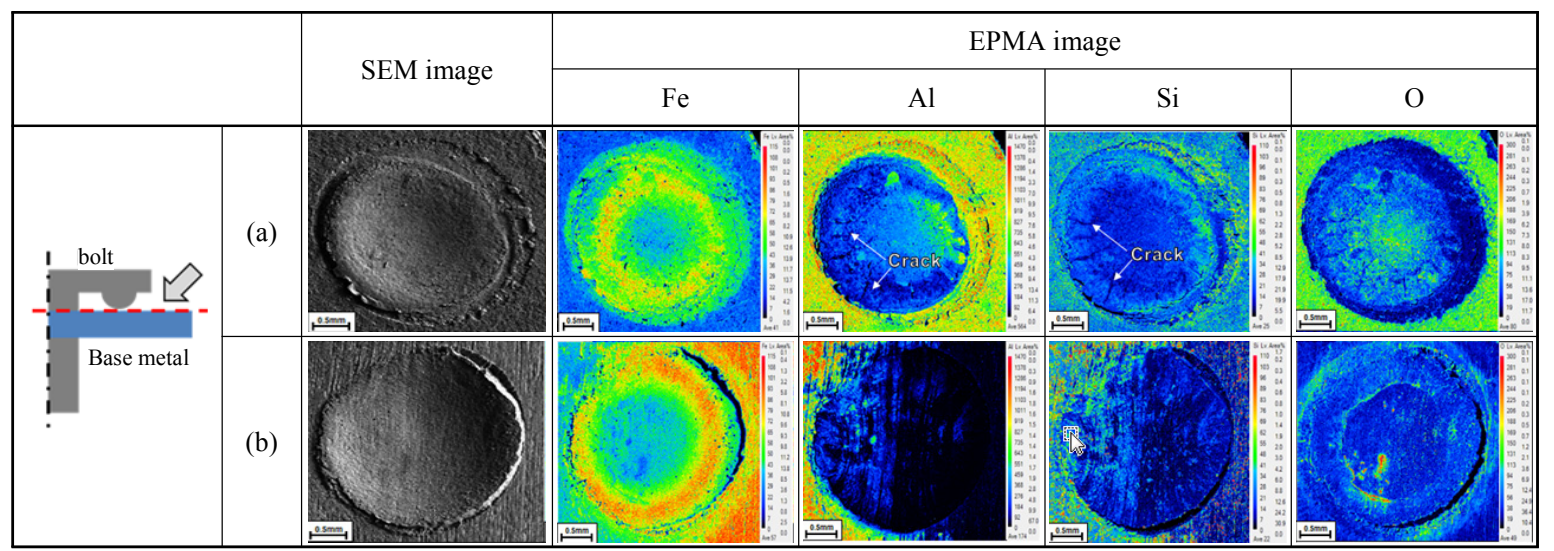

Fig. 7 EPMA mapping of the elemental distribution in the coating layer at the faying surface at $11 \mathrm{kA}-2$ cycle, (a) Al- Si coated hot stamped boron steel, (b) None Al-Si coated hot stamped boron steel

강은 용접부 계면에서 다수의 균열과 볼트 돌기 접촉부 를 중심으로 도넛 형태의 형상이 관찰되었다. 도금층의 용융이 완벽하게 이루어지지 않아 잔존하는 도금층이라 고 추정했지만 본 현상에 대한 명확한 성분 규명을 위 해 Fig. 7과 같이 EPMA 성분 Mapping 분석을 이용 하여 용접부 표면의 성분을 분석·비교해 보았다.

분석 결과 $\mathrm{Al}-\mathrm{Si}$ 도금된 핫스탬핑강의 용접부 계면 중심에서 도금층의 주성분인 $\mathrm{Al}, \mathrm{Si}$ 의 성분이 Bare 핫스탬핑 보론강 보다 휠씬 높은 피크를 보였으며 Fig. 6 에서 관찰된 용접부 중심으로 형성된 외각의 도넛 형 상에서는 $\mathrm{Al}, \mathrm{Si}$ 성분이 높게 관찰되었다. 이는 $\mathrm{Al}-\mathrm{Si}$ 도금된 핫스탬핑 보론강 저항 점 용접 시 용융 초기에 용접부 계면에서 용융된 액상 상태의 도금층이 용접부 외각으로 빠져나가 접합 계면에 고체 상태로 존재하는 것으로 사료되며 핫스탬핑 보론강 저항 점 용접에서도 이와 같은 현상이 있는 것으로 보고되었다. 또한 $\mathrm{Al}-\mathrm{Si}$ 도금된 핫스탬핑강 용접부 계면에서 관찰된 균열 부위 에서 $\mathrm{Al}, \mathrm{Si}$ 의 성분이 미비하게 나타났고 이는 용접부 외각으로 빠져나가지 못한 도금층이라고 판단되며, 잔 존한 도금층의 Brittle 한 특성에 의한 것으로 판단된 다 $^{15)}$. 또한 Bare 핫스탬핑 보론강에 비해 $\mathrm{Fe}$ 성분은 낮게 $\mathrm{O}$ 성분은 상대적으로 높게 검출된 것을 미루어 볼 때 외각 쪽으로 용융되지 못한 도금층에 의해 충분 한 접촉면적을 확보하지 못한 것으로 판단된다.

$\mathrm{Al}-\mathrm{Si}$ 도금된 핫스탬핑 보론강의 볼트 프로젝션 용접 시 외각 쪽으로 용융된 도금층의 거동을 분석하기 위해 용접부 단면을 EPMA를 이용하여 성분 Mapping 하 였다(Fig. 8). 분석 결과 용접부 외각에 $\mathrm{Al}-\mathrm{Si}$ 도금층 으로 판단되는 이물질을 관찰하였으며, 이를 성분 분석 한 결과 $\mathrm{Al}, \mathrm{Si}$ 의 성분이 높게 검출되어 Fig. 6와 Fig. 7에서 관찰된 용접부 외각의 도넛 형상은 도금층이 용 융되면서 외각으로 밀려난 $\mathrm{Al}-\mathrm{Si}$ 도금층으로 판단된다.

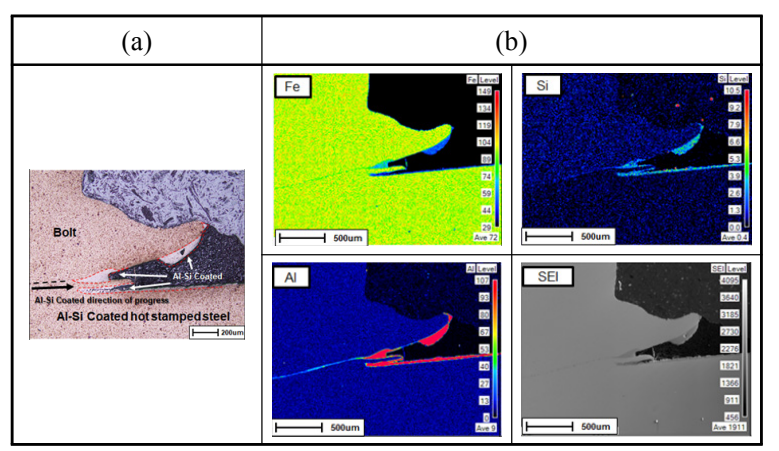

Fig. 8 Obsevation of cross-sectional image of periphery in bolt projection welds for the Al-Si coated hot stamped boron steel, (a) OM image (b) EPMA mapping of elements distribution (electrode force $570 \mathrm{kgf}$ and weld current $13 \mathrm{kA}$ and weld time 2 cycle)

용접부 외각에서 관찰된 도금층은 원래의 도금층보다 $4 \sim 5$ 배 두꺼운 용융물로 관찰되었으며, 본 도금층은 두 꺼운 두께로 인한 높은 저항값으로 인하여, 외각 쪽의 전 류 통전을 방해하여 용접부 성장 및 확장에 좋지 않은 영향을 미치는 것으로 판단된다. 다음 장에는 핫스탬핑 보론강의 $\mathrm{Al}-\mathrm{Si}$ 도금층이 실제 용융부의 성장 거동에 미치는 영향을 실시간으로 관찰하기 위해 초고속 카메 라를 이용해 비교·관찰해보았다.

\section{4 용융부 성장거동 메커니즘}

앞장에서 고찰된 용융 거동에 대한 직·간접적인 용융 성장 거동을 실시간으로 용접부 단면의 영상 찰영을 이 용해 관찰해보았다. Fig. 9는 용접 시 중간날림 현상이 발생하지 않는 용접조건에서 실시간 초고속 카메라를 이 용해 $\mathrm{Al}-\mathrm{Si}$ 도금된 핫스탬핑 보론강과 Bare 핫스탬핑 보론강의 용융부 성장 거동을 비교한 결과이다. 도금층 유무에 따라 접합계면에서 발열현상에 차이가 발생하는 


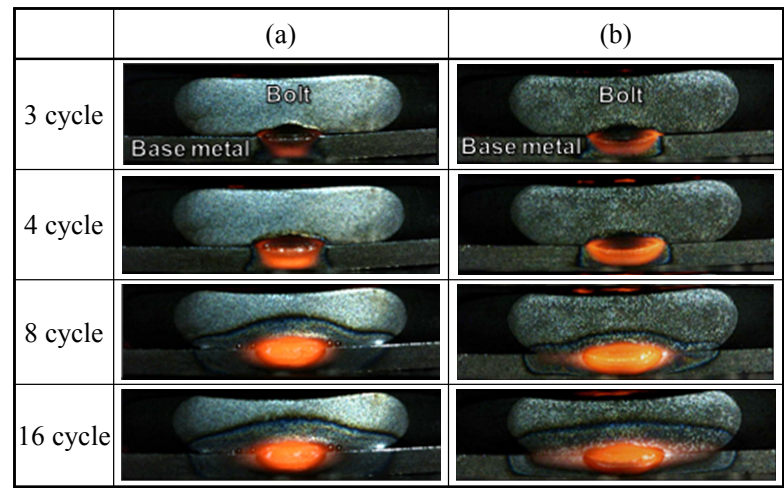

Fig. 9 High speed camera image of nugget growth observation ; (a) Al-Si coated hot stamped boron steel (b) Non Al-Si coated hot stamped boron steel (electrode force $570 \mathrm{kgf}$, weld current $12 \mathrm{kA}$ and weld time 16 cycle)

것을 확인하였고, 볼트보다는 상대적으로 높은 표면 및 모재 저항 특성을 지닌 핫스탬핑 강판 쪽에서 용융 현상 및 열 영향부의 형태가 더 많이 나타났다. Fig. 9(a)의 $\mathrm{Al}-\mathrm{Si}$ 도금된 핫스탬핑 보론강의 경우 용접 초기 시간 (3 cycle)에서 도금층의 용융이 발생하였다. 그리고 $\mathrm{Al}-$ $\mathrm{Si}$ 도금된 핫스탬핑강판에서의 상대적으로 넓은 열영향 부 및 작은 너겟경이 형성된 것을 미루어볼 때, $\mathrm{Al}-\mathrm{Si}$ 도금층이 발열현상 및 통전면적을 확장함에 있어 큰 영 향을 미쳤다고 판단된다. Fig. 9의 이미지를 기반으로 하여 Fig. 10은 용접 시간에 따른 용접부의 길이 방향 (너겟경)과 높이 방향의 크기를 측정하여 그래프로 나 타낸 결과이다. 용접 시간이 증가함에 따라 너겟경이 높 이, 길이 방향으로 성장하다 약 $7 \mathrm{cycle}$ 이상에서 성장이 멈췼고, 볼트 돌기의 직경으로 인한 계속적인 너겟의 성장에는 한계가 있었다. Fig. 10(a)의 경우 $\mathrm{Al}-\mathrm{Si}$ 도 금된 핫스탬핑 보론강의 너겟이 Bare 핫스탬핑 보론강 의 보다 빠른 속도로 성장하였고 높이 방향으로 더 크 게 성장하였다. Fig. 10(b)의 경우, 너겟 직경의 성장 속도는 유사하였지만 Bare 핫스탬핑 보론강의 너겟경 이 훨씬 크게 성장하였다. $\mathrm{Al}-\mathrm{Si}$ 도금된 핫스탬핑 보론 강의 도금층의 높은 접촉저항에 기인한 발열 접촉부에 서의 발열 현상이 초기 용접부 높이 방향 성장 속도 및 너겟의 높이에 영향을 미친 것으로 판단된다.

또한 용접 초기 $\mathrm{Al}-\mathrm{Si}$ 도금층이 외각으로 밀려나가면 서 축척된 도금층으로 인해 충분한 접촉 면적이 확보되 지 못하고, 너겟경이 확장하기 위한 통전을 방해하여 $\mathrm{Al}-\mathrm{Si}$ 도금된 핫스탬핑 보론강의 너겟경이 성장이 제한 되었다고 사료된다.

앞선 연구 결과를 바탕으로 $\mathrm{Al}-\mathrm{Si}$ 도금된 핫스탬핑 보론강과 Bare 핫스탬핑 보론강의 용융부 성장 거동을 모식도로 Fig. 11에 나타내었다. Fig. 11(a)의 Al-Si
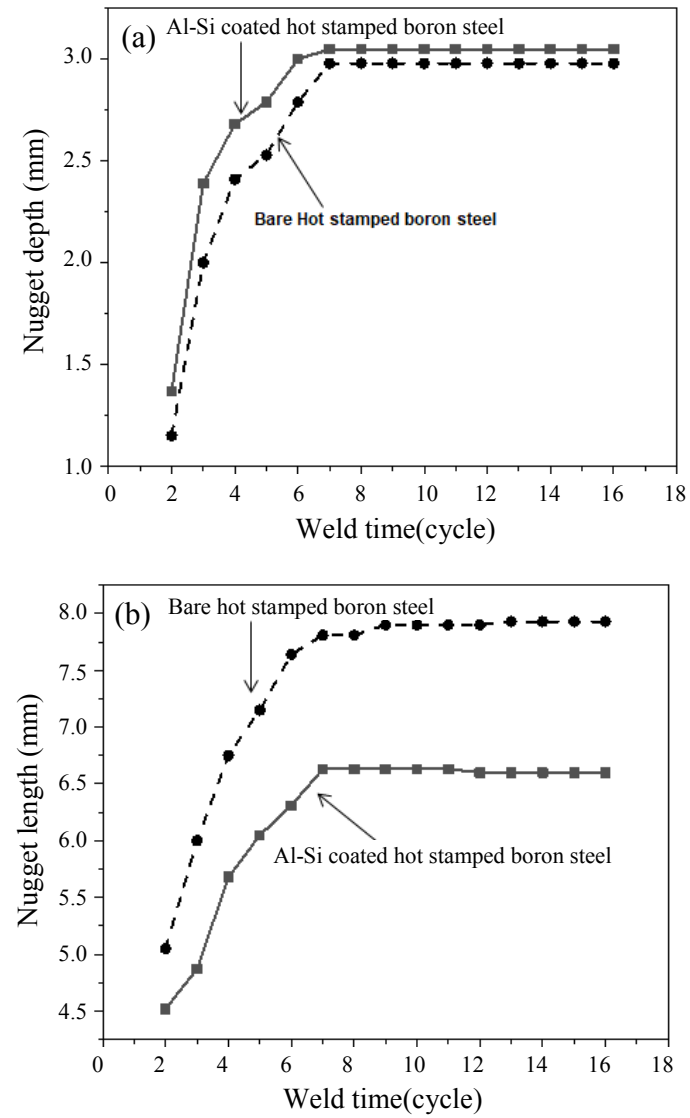

Fig. 10 Nugget growth with weld time for bolt projection welded Al-Si coated, and Bare hot stamped boron steel (electrode force $570 \mathrm{kgf}$ and weld time 16 cycle), (a) nugget height growth, (b) nugget length growth

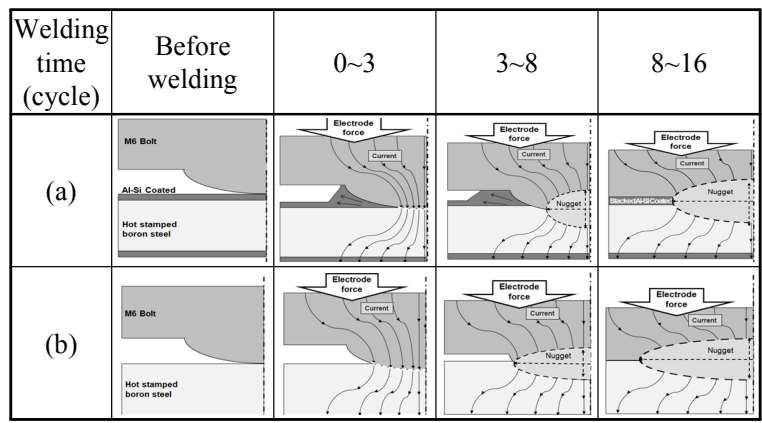

Fig. 11 Schematic diagram of nugget growth behavior ; (a)Al-Si Coated hot stamped boron steel (b)Bare hot stamped boron steel

도금된 핫스탬핑 보론강 용접 시 도금층 및 산화층으로 인한 표면의 높은 발열이 발생하며 용융된 도금층은 액 체의 필름 형태로 용접부 외각으로 밀려나게 된다. 이 때 외각에 모여 축적된 액상의 도금층은 접촉면적 형성 및 원활한 전류 통전을 방해하고, 너겟을 높이 방향으 로 성장을 유도하게 된다. 이로 인하여 제한적인 너겟 
경의 성장으로 용착 강도 저하 및 계면 파단 등 용접 불량이 발생하는 것으로 판단된다. 하지만 Fig. 11(b) 와 같이 Bare 핫스탬핑 보론강의 경우는 초기에 넓은 접촉면적을 확보하여 상대적으로 낮은 발열이 발생하 고, 용접 시간이 증가함에 따라 충분한 접촉면적을 확 보하면서 너겟이 길이 방향으로 성장하기 때문에 $\mathrm{Al}-\mathrm{Si}$ 도금된 핫스탬핑 보론강의 용접부 너겟경에 비해 큰 너 겟경을 확보할 수 있다고 판단된다.

\section{4. 결 론}

본 연구에서는 도금층 유무에 따른 가용전류구간 및 동저항 곡선을 통해 용접성의 차이를 비교하고, 용접성 의 차이를 규명하기 위해 $\mathrm{Al}-\mathrm{Si}$ 도금층의 초기 용융 거 동 및 그에 따른 실제 용접부 성장 거동을 분석하여 $\mathrm{Al}-\mathrm{Si}$ 도금층이 용접성에 미치는 영향에 대해 고찰해보 았다.

1) $\mathrm{Al}-\mathrm{Si}$ 도금된 핫스탬핑 보론강은 Bare 핫스탬핑 보론강에 비해 용접부 최대 강도가 낮고 가용전류구간 이 협소하였다. 이는 $\mathrm{Al}-\mathrm{Si}$ 도금층의 존재 여부에 따른 발열현상의 차이가 용접 특성에 큰 영향을 미친 것으로 판단된다.

2) $\mathrm{Al}-\mathrm{Si}$ 도금층 유무에 따른 용접 해석 시뮬레이션 과 동저항 비교 결과 $\mathrm{Al}-\mathrm{Si}$ 도금된 핫스탬핑 보론강 용 접 시 용융 초기 볼트 돌기의 붕괴가 늦게 발생하고, 접촉면적이 확보되지 못하였으며 용융 면적 또한 작은 것으로 관찰되었으며, $a-p e a k$, 초기 동저항, 동저항 면 적이 높게 나타났다. 이는 합금화층 내 $\mathrm{Fe}$ 에 $\mathrm{Al}-\mathrm{Si}$ 가 일부 고용된 형태로 존재하는 합금화층의 영향에 기인 한 것으로 판단된다.

3) $\mathrm{Al}-\mathrm{Si}$ 도금된 핫스탬핑 보론강의 도금층은 용융 초기 용접부 계면에서 용융된 액상 상태로 용접부 외각 에 빠져나가 접합 계면에 고체 상태로 축적되어 존재하 는 것으로 관찰되었으며, 이때 용접부 외각으로 빠져나 가지 못한 일부 도금층에 의해 충분한 접촉면적을 확보 하지 못하였고, 외각에 모여 축적된 도금층의 높은 저 항으로 인해 용접부 외각의 전류 통전을 방해하여 용접 부 성장 및 확장에 좋지 않은 영향을 미치는 것으로 나 타났다.

4) $\mathrm{Al}-\mathrm{Si}$ 도금층이 존재하는 경우 상대적으로 넓은 열영향부 및 작은 너겟경이 형성되었으며, 용접 초기 $\mathrm{Al}-$ $\mathrm{Si}$ 도금층의 높은 접촉저항으로 인해 용접부 높이 방향 성장을 촉진시키고, 외각으로 밀려나가 축적된 $\mathrm{Al}-\mathrm{Si}$ 도 금층이 너겟경 확장을 위한 통전을 방해하여 길이 방향 으로 성장하지 못해 너겟경 성장이 제한되었다.
후 기

본 연구는 중소벤처기업부와 한국산업기술진흥원의 "지역 특화육성(R\&D, P0002883)"사업의 지원을 받아 수행된 연 구결과임.

ORCID: Jae-Hun Kim: http://orcid.org/0000-0002-4040-0856 ORCID: Chang-Wook Ji: http://orcid.org/0000-0002-5158-5243

\section{References}

1. H. Karbasian and A.E. Tekkaya, A review on hot stamping, J. Mater. Processing Technol. 210 (2010) 20132118.

https://doi.org/10.1016/j.jmatprotec.2010.07.019

2. G. Zhong-xing, Thermo-mechanical behavior of the AlSi alloy coated hot stamping boron steel, Mater. Des. 60 (2014) 26-33.

https://doi.org/10.1016/j.matdes.2014.03.011

3. S. Smith, The effect of ageing on the spot weld strength of AHSS and the consequences for testing procedures, Weld. World, 54 (2010) 12-26. https://doi.org/10.1007/BF03263480

4. H. Oikawa, Resistance Spot Weldability of High Strength Steel Sheets for Automobiles and the Quality Assurance of Joints, Weld. World, 51.3-4 (2007) 7-18. https://doi.org/10.1007/BF03266555

5. S. S. Park, Evaluation of Resistance Spot Weld In- terfacial Fractures in Tensile-Shear Tests of TRIP 1180 Steel, J. Korean Weld. Join. Soc. 26(6) (2008) 81-91. https://doi.org/10.5781/KWJS.2008.26.6.081

6. C.W. Ji, Optimization of pulsed current in resistance spot welding of $\mathrm{Zn}$-coated hot-stamped boron steels, $J$. Mech. Sci. Tech, 33(4) (2019) 1615-1621. https://doi.org/10.1007/s12206-019-0313-2

7. S. S. Lim, Effect of Chemical Composition of Nut Material on the Fracture Behavior in Nut Projection Welding of Hot-Stamped Steel Sheet J. Weld. Join. 34(2) (2016) 1-10. http://dx.doi.org/10.5781/JWJ.2016.34.2.1

8. E. J. Chun, Influence of heat-treated Al-Si coating on the weldability and microstructural inhomogeneity for hot stamped steel resistance nut projection welds Met. Mater. Int. 25 (2019) 179-192. https://doi.org/10.1007/s12540-018-0108-5

9. Z. Han, Resistance spot welding: a heat transfer study, Welding journal, 68.9 (1989) 363s-371s.

10. P. S. Wei, Electrical contact resistance effect on resistance spot welding, Int. J. Heat Mass Transfer, 55 (2012) 3316-3324. https://doi.org/10.1016/j.ijheatmasstransfer.2012.01.040

11. S. A. Gedeon, Measurement of dynamic electrical and mechanical properties of resistance spot welds, Weld. J. 
66(12) (1987) 378-385.

12. Y. Cho, Experimental study of nugget formation in resistance spot welding, Weld. J. 82(8) (2003) 195/S201/S.

13. P. S. Wei, Electrical contact resistance effect on resistance spot welding, Int. J. Heat Mass Transfer, 55 (2012) 3316-3324.

https://doi.org/10.1016/j.ijheatmasstransfer.2012.01.040
14. C. W. Ji, Study on Coating Melting Behavior on Weld Growth Mechanism for Al-Si coated Hot- Stamped Boron Steels in Resistance Spot Welding, Korean J. Met. Mater., 52 (2014) 931-941.

http://dx.doi.org/10.3365/KJMM.2014.52.11.931

15. D. C. Saha, Coating behaviour and nugget formation during resistance welding of hot forming steels, Sci. Technol. Weld. Join. 20(8) (2015) 708-720.

http://dx.doi.org/10.1179/1362171815Y.0000000054 